\title{
Levantamento das descontinuidades e avaliação da estabilidade de taludes da mina do Mangueirão
}

\author{
Survey of discontinuities and evaluation of the slope stability at Mangueirão mine
}

Valmor Madeira Paz'1, Ítalo Gomes Gonçalves², Raul Oliveira Neto², Luis Eduardo de Souza², Luciana Arnt Abichequer $^{2}$

${ }^{1}$ Tecnólogo em Mineração, Universidade Federal do Pampa, Caçapava do Sul,RS, Brasil

${ }^{2}$ Engenheiro(a) de Minas/Professor do Programa de Pós-Graduação em Tecnologia Mineral (PPGTM), Universidade Federal do Pampa, Caçapava do Sul, RS, Brasil

\begin{abstract}
Resumo
O estudo e o controle da estabilidade de taludes têm crescido muito nas últimas décadas, logo a qualidade e a confiabilidade dos resultados de uma análise destas estabilidades são muito importantes, pois proporcionam economia para o empreendedor e segurança para os trabalhadores. Este artigo tem como objetivo abordar os aspectos geológico-geotécnicos considerados mais importantes para a estabilidade de taludes de escavação em maciços rochosos. Para alcançar tal objetivo, foi realizada uma revisão das características das descontinuidades, como: espaçamento, orientação, abertura, preenchimento, percolação e rugosidade de fraturas. Através de scanlines, foram confeccionados histogramas de frequência destas descontinuidades, projeções estereográficas através do software stereonet9 e identificação das principais famílias de descontinuidades, pois são estas estruturas os principais condicionantes dos modos de ruptura em maciços rochosos. Para tal, foram selecionados sete taludes, com evidências de instabilidades, que foram sujeitos a um conjunto de estudos de campo para obtenção dos parâmetros necessários para se chegar ao fator mínimo de segurança. Desta forma, foram simuladas oito situações de avanço de lavra com intervalos de $45^{\circ}$, que em três delas foram obtidos resultados satisfatórios, atendendo à expectativa do trabalho desenvolvido.
\end{abstract}

Palavras-chave: Scanline. Descontinuidades. Projeções-estereográficas. Fator de segurança. Estabilidade de taludes.

\begin{abstract}
The study and control of slope stability have grown greatly in recent decades, so the quality and the reliability of the results of an analysis of stability are very important because they provide savings for the enterprise and security for workers. This article aims to address the geological and geotechnical aspects considered most important for the stability of slope excavation in rock masses. To achieve this goal, a review of the characteristics of discontinuities was held as spacing, orientation, opening, filling, percolation and roughness fractures. Through scanlines, was made histogram frequency of these discontinuities, stereographic projections in the software stereonet9 and identification of the main families of discontinuities, because the main determinants of failure modes in rock masses are these structures. To do so, seven slopes were selected, with evidence of instability, which were subjected to a series of field studies to obtain the parameters necessary to reach the minimum safety factor. In this way situations were simulated eight $45^{\circ}$ intervals with mining advance, that in three of them were obtained satisfactory results, given the expectation of work.
\end{abstract}

Keywords: Scanline, discontinuities, stereographic projections, safety factor, slope stability. 


\section{Introdução}

No presente trabalho foram abordados os aspectos geomecânicos envolvidos no comportamento de taludes de escavação em maciços rochosos. O principal objetivo foi analisar as condições de estabilidade de taludes de escavação e estimar um fator de segurança e um avanço de lavra seguro para equipamentos e operários na mina a céu aberto mangueirão, na empresa Dagoberto Barcellos S/A do grupo DB de Caçapava do Sul. O local de estudo encontra-se inserido no Complexo Vacacai, a qual é composta principalmente por calcário calcítico e dolomítico metamorfizado, A unidade metavulcanossedimentar é constituída por lentes de mármore e xistos provenientes de metapelito, grafita xisto, quartzitos, anfibolito e níveis de metavulcânicas intermediárias, todo o conjunto metamorfizado. Intrusões graníticas, metapelitos, diabásios e outros contaminantes, fazem com que o desmonte desta mina seja distinto, ou seja, desmonta-se primeiro minério ou estéril, acompanhando sempre o mergulho do corpo, para melhor seletividade do produto, mas isto resulta em bancadas irregulares, comprometendo muitas vezes a instabilidade de taludes. Na busca de um fator de segurança e um avanço de lavra seguro, foi necessário estudar as características mecânicas e estruturais dos maciços rochosos que constituem estes taludes de escavação. Alguns destes taludes apresentam-se com claras evidências de instabilidade, podendo-se observar a existência de cunhas e blocos destacados.

\section{Revisão bibliográfica}

Diversas abordagens para determinação das características geológicas e geomecânicas dos maciços rochosos são apresentadas pela literatura, mostrando à importância e influência que o estudo das descontinuidades, tem na compreensão dos mecanismos de ruptura de um talude. Estas rupturas podem ser pequenas e locais ou, ao contrário, assumir grandes proporções, com conseqüências graves e onerosas. A análise estrutural das descontinuidades atuante em um maciço rochoso é de essencial importância em vários seguimentos da geologia aplicada. Parâmetros como frequência, orientação, abertura, preenchimento, percolação e rugosidade de fraturas são importantes em diversas classificações geomecânicas de maciços (Fiori \& Carmignani 2009). A caracterização das descontinuidades é um fator fundamental na análise da estabilidade de escavações subterrâneas e a céu aberto, nos proporciona o entendimento da história deformacional do maciço levando a um melhor entendimento da tectônica rúptil regional atuante nessas rochas. Estudar as deformações que ocorrem em um maciço rochoso não é somente importante para o entendimento da estrutura do maciço, mas para o reconhecimento das forças atuantes nele e suas direções. Desenvolver um modelo estrutural de um maciço rochoso ajuda a entender melhor a distribuição espacial das descontinuidades e suas características geométricas, desta forma permite reconhecer as mais importantes, que por sua vez com o avanço dos estudos definem a gênese tectônica de seu arranjo estrutural (Fernandes, 2010).

\subsection{Características das descontinuidades}

Uma descontinuidade é qualquer quebra mecânica ou fratura presente num maciço rochoso, sendo importante qualificar a sua origem, podendo ser natural ou artificial devido ao desmonte da rocha por explosivos (Fiori \& Carmignani 2009). Segundo Fiori \& Carmignani (2009), as principais características das descontinuidades com implicações no comportamento geotécnico dos maciços fissurados são, a orientação, o espaçamento, a persistência, a rugosidade, o enchimento, abertura, percolação nas descontinuidades e o estado de meteorização das respectivas paredes. São essas descontinuidades que governam em regra o comportamento mecânico do maciço, pois são as estruturas menos resistentes, designadamente nas situações de rupturas relacionadas com deslizamentos verificados ao longo de superfícies de anisotropias bem definidas (Fontinhas 2009). Para entender melhor o comportamento 
do maciço rochoso antes, durante e depois da escavação, é necessário um estudo da intensidade das fraturas. Segundo Fontinhas (2009) um sistema de classificação confiável baseado no comportamento geomecânico dos taludes, tem de ter em conta os seguintes aspetos: características globais do maciço rochoso; diferença de direções entre a face do talude e a das descontinuidades; diferença entre o ângulo de inclinação das descontinuidades e o do talude, característica de que depende o fato de as descontinuidades emergirem a face do talude, condição necessária para ruptura planar e/ou ruptura por cunha; relação entre ângulo de inclinação das descontinuidades e ângulo de atrito; relações entre a resistência ao cisalhamento, com o ângulo de atrito das descontinuidades.

\subsubsection{Scanline}

No presente trabalho foi utilizada a medição com auxilio da scanline, que consiste em anotar o espaçamento entre as descontinuidades sempre que estas intersectavam a linha de varredura. O objetivo foi a elaboração de um modelo geológico-estrutural. O levantamento de fraturas em campo é em geral bastante trabalhoso, envolvendo, além do mapeamento tradicional, a coleta de centenas de atitudes. Uma amostragem completa das descontinuidades das rochas, linear, por área ou volumétrica, pelos métodos tradicionais, tem a desvantagem de ser muito demorada e muitas vezes não ser possível. Uma amostragem efetiva das descontinuidades existentes em um maciço não deve deixar uma porção subestimada nem conter mais amostras do que o necessário. Nesse sentido, o método da linha de varredura (scanline) mostra-se de grande eficiência (Fernandes 2010).

\subsubsection{Orientação}

Em Geologia entende-se por atitude de um plano, sua direção (strike) mergulho (dip) e (dip direction), estas são tomadas com auxilio de uma bússola. Strike é a linha de intersecção entre o plano e a horizontal, perpendicular ao dip direction, ou seja, é o ângulo que uma linha horizontal do plano faz com o Norte (azimute); e o mergulho é dado por uma linha perpendicular ao strike (linha de maior declive), sendo que o azimute desta linha nos dá o sentido do mergulho e o ângulo que esta linha faz com a horizontal nos dá o ângulo de mergulho. O mergulho aparente é o ângulo que qualquer linha oblíqua ao sentido, faz com um plano horizontal. A atitude de um plano geológico é uma forma de localizar e representar este plano em mapa, pois cada plano tem uma, e somente uma, atitude, como pode ser observado na Figura 1. A avaliação da atitude das descontinuidades, que é normalmente definida por esses dois parâmetros (strike e dip), permite identificar as famílias de descontinuidades singulares, que são determinantes no estudo dos problemas de estabilidade. (Fiori \& Carmignani 2009)
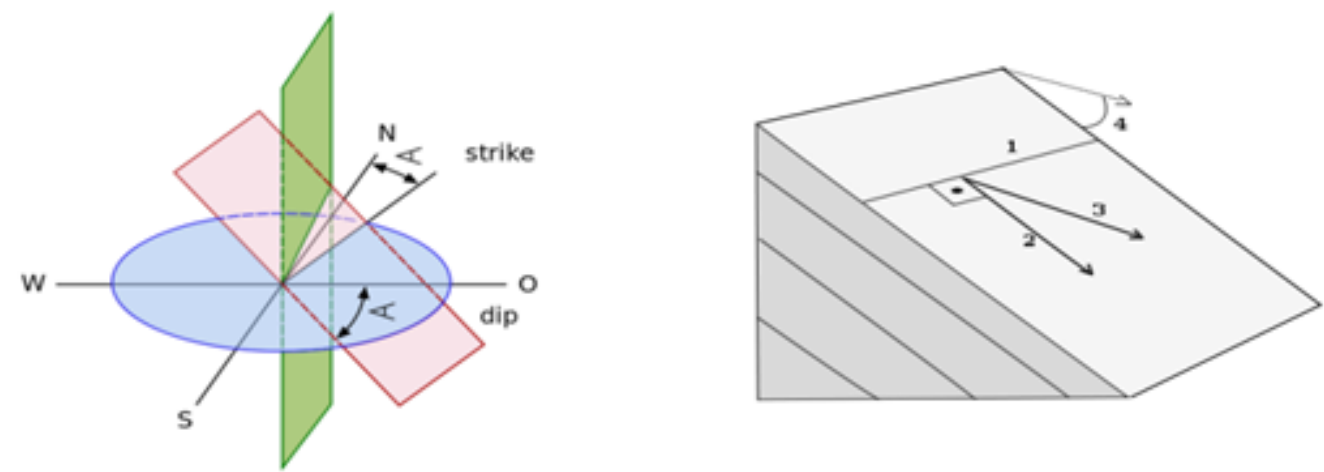

Figura-1- Representação de atitudes de um plano de descontinuidade. 1- Strike ângulo com o Norte; 2-(Dip) Mergulho da descontinuidade; 3-Mergulho aparente e 4 - (Dip direction) da descontinuidade. Fonte: Wikipedia 


\subsubsection{Espaçamento ou frequência}

O espaçamento ou frequência das descontinuidades pode ser definido como a distância entre descontinuidades, sendo esta distância medida por uma linha de varredura (scanline) na face de um talude, ou ao longo de um testemunho de uma sondagem. Segundo Fiori \& Carmignani (2009), o espaçamento é dado pelo o inverso da frequência, e pode ser definido pela equação:

$$
x=\frac{L}{N}
$$

Onde L é o comprimento perpendicular ao plano das descontinuidades intersectadas por $\mathrm{N}$ descontinuidades, a qual pode ser definida como o número de descontinuidades por metro, já a freqüência $\lambda$, é dada pela equação:

$\lambda=\frac{1}{x}$

A freqüência das descontinuidades costuma ser bem modelada pela distribuição exponencial pela formula:

$(x)=\lambda e^{-\lambda x}$

O espaçamento influencia também na permeabilidade do maciço e as suas características de percolação. A definição do espaçamento das descontinuidades tem como objetivo determinar a dimensão dos blocos em que o talude se encontra compartimentado, este parâmetro está relacionado com a sua estabilidade, pois as forças que atuam na sua instabilidade são dependentes dos seus volumes (Fiori \& Carmignani 2009).

\subsubsection{Persistência ou extensão}

Um plano de descontinuidade apresenta basicamente três componentes: áreas com segmentos totalmente separados ou sem coesão, áreas com porções de rochas intactas e áreas de segmentos enfraquecidos. A persistência é representada pela extensão de uma descontinuidade medida num plano, é um dos parâmetros que mais influenciam no comportamento mecânico e hidráulico do maciço rochoso e, é uma das características mais difíceis de serem determinadas, pois não se sabe o comportamento delas no interior do talude. A persistência condicionada à estabilidade do talude influencia nas dimensões do material rochoso, presente nos processos de instabilidade, e influencia também nos valores da permeabilidade do maciço. As descontinuidades mais extensas devem ter um estudo mais aprofundado, pois elas que vão determinar os principais planos de ruptura (Fiori \& Carmignani 2009).

\subsubsection{Rugosidade}

A rugosidade pode ser definida pelas irregularidades e ondulações presentes nas superfícies das descontinuidades, e determina a resistência ao cisalhamento das mesmas. A rugosidade influencia na resistência ao deslizamento de uma descontinuidade, principalmente quando se encontra fechada, a rugosidade aumenta a resistência ao cisalhamento, e a sua influência na resistência diminui com o aumento da abertura ou do enchimento (Fiori \& Carmignani 2009). O valor de resistência que a rugosidade fornece varia de acordo com a sua direção, logo, é importante saber a direção provável do movimento para estudos de estabilidade. A rugosidade das paredes das descontinuidades pode ser medida através de comparação visual destas com perfis padrão de rugosidade (Fontinhas, 2012 apud ISRM, 1978). Estes perfis permitem classificar as paredes das descontinuidades primeiramente indentadas, onduladas e planares, lisas ou espelhadas. 
A abertura é a distância média que separa paredes adjacentes de uma descontinuidade, onde esse espaço pode ser preenchido por ar, água ou materiais diversos. A abertura das descontinuidades varia em diferentes zonas do maciço rochoso, uma mesma descontinuidade pode apresentar abertura de vários centímetros na superfície e em profundidade estar completamente fechada ou vice versa. Esta diferença está relacionada com a descompressão dos maciços rochosos, com o estado de meteorização, com a ocorrência de deslocamentos de descontinuidades que apresentam uma elevada rugosidade ou ondulação, ou com a existência de fenômenos de dissolução e de lavagem de fraturas (Fontinhas, 2012).

\subsubsection{Enchimento}

Enchimento é definido como o material que preenche total ou parcialmente o espaço entre as paredes das descontinuidades, podendo ser composto por materiais desde os mais brandos, argilosos, aos mais resistentes, como xisto, ou intrusões graníticas. O enchimento é outro parâmetro que dita o comportamento mecânico da descontinuidade. Uma proposta para a caracterização do enchimento foi apresentada por, (Fontinhas 2012 apud ISRM 1978) a qual sugere que qualquer medição deve ser feita diretamente com régua graduada, devendo também ser efetuada uma descrição do enchimento, incluindo a identificação da mineralogia do material e do tamanho de grão, assim como indicação do teor em água e estimativa qualitativa da permeabilidade do mesmo material. Estes aspetos condicionam as características de percolação da água nas descontinuidades, o que diminui a resistência ao deslizamento principalmente os enchimentos argilosos que são desfavoráveis à resistência ao cisalhamento das descontinuidades na existência de água. O preenchimento parcial com pontos de contatos rocha-rocha é o que apresenta maior dificuldade de análise (Fiori \& Carmignani 2009).

\subsubsection{Percolação}

Segundo Fiori \& Carmignani (2009), o grau de saturação representa a porcentagem do volume de vazios do solo que contém água. A percolação é uma das principais características que condicionam as situações de instabilidade dos taludes e pode surgir associada aos planos de descontinuidades, é difícil distinguir a água que percola pelas fraturas como a que escorre superficialmente. Se houver existência de percolação de água em uma descontinuidade, seu fluxo deve ser estimado, fazendo uma análise dos resultados obtidos com base nas condições climáticas e no conhecimento da posição dos níveis de água no interior do maciço.

\subsection{Talude}

Um talude é uma superfície de fronteira entre o ar e a rocha, natural ou artificial, vertical ou inclinada, ou o corpo de uma obra de terra, como uma barragem ou um aterro. As condições de estabilidade, exigidas para os taludes da mineração, diferem daquelas de outros taludes de obras civis, basicamente, pela dinâmica da escavação, pelo porte das mesmas, atingindo alturas de centenas de metros e extensão de quilômetros e, ainda, pelas condições peculiares, tais como fatores de segurança menores, aceitação de rupturas localizadas, convivência com vibrações causadas por desmonte com explosivos, rebaixamento do nível d'água buscando taludes mais íngremes, possibilidade de experimentação de ângulos de talude à medida do avanço da lavra, etc. 


\subsection{Fator de segurança}

A segurança de um projeto de engenharia é usualmente avaliada através de um fator de segurança (FS), definido como a razão entre a resistência disponível e o carregamento atuante. Segundo Fiori \& Carmignani (2009) a resistência ao cisalhamento mobilizada deverá ser igual à tensão cisalhante aplicada, desta forma o fator de segurança poderá ser expresso como:

$F s=\frac{\operatorname{tg} \phi \text { disponivel }}{\operatorname{tg} \phi \text { mobilizado }}$

A adoção de um valor de FS mínimo admissível para uma determinada obra implica na adoção de um risco calculado ou aceitável, valores de FS maiores que 1 indicam estabilidade, valores de FS menores do que 1 indicam instabilidade, e valores de FS igual a 1 indicam condições limites de estabilidade (meta-estabilidade). No entanto, deve-se observar que a probabilidade de ocorrência de um deslizamento não é função linear do fator de segurança.

\subsection{Resistência ao cisalhamento de descontinuidades}

Resistência ao cisalhamento é a resistência que os corpos rochosos têm para se romperem segundo a direção das tensões cisalhantes, ou seja, na direção tangencial. O fator mais importante para a determinação desta resistência é a geometria da rocha, em seguida, pode-se citar a resistência ao cisalhamento das superfícies com potencial de ruptura (Fiori \& Carmignani 2009). A determinação do valor da resistência ao cisalhamento $\left(\tau_{\max }\right)$ e a tensão normal $(\sigma)$ é representada pela equação de

Mohr - Coulomb:

$\tau_{\max }=c+\sigma \tan \phi$

Onde $c$ é a resistência coesiva do material cimentado e $\phi$ o ângulo de atrito no qual um corpo em

repouso sobre uma superfície inclinada, supera a resistência de atrito e começa a deslizar medido entre a normal à superfície e a resultante das forças que atuam sobre o corpo. A análise da resistência ao cisalhamento é um ponto crítico no projeto de estabilidade da mina, pois uma pequena variação no valor determinado pode provocar mudanças consideráveis nesta estabilidade (altura e inclinação do talude). Vários fatores podem provocar mudanças no valor da resistência, como a rugosidade das superfícies, intemperismo e presença de água. Estas equações necessitam de valores estimados ou calculados para a resistência à compressão, para o ângulo de atrito e para a média do ângulo de rugosidade da superfície (Fiori \& Carmignani 2009).

O diagrama de Mohr (Figura 2) mostra o comportamento da resistência ao cisalhamento para três tipos de descontinuidades e dois tipos de maciços rochosos. A inclinação de cada linha ou envoltória expressa o ângulo de atrito, de forma que o intercepto com o eixo do esforço de corte, expressa a coesão. 


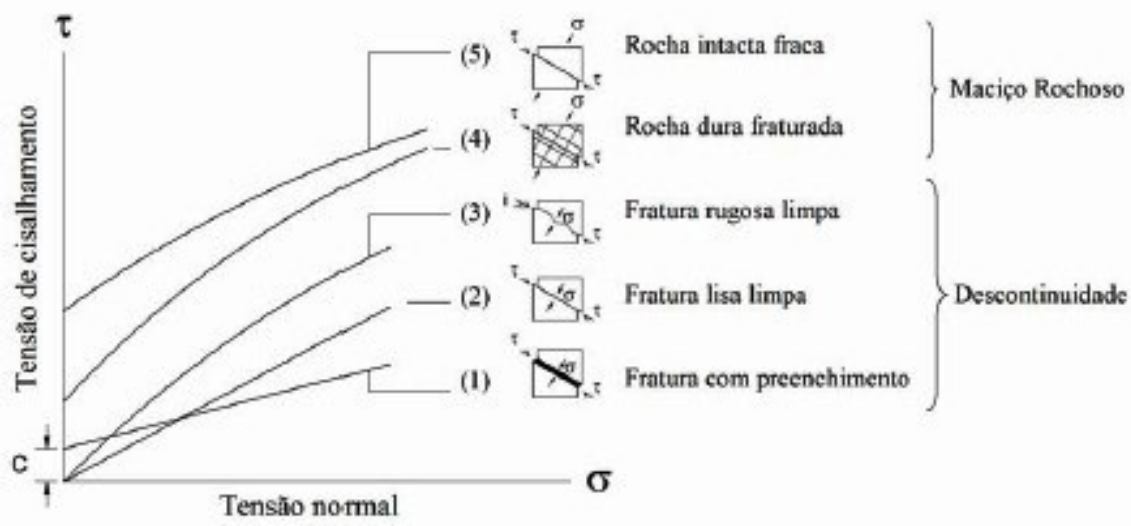

Figura 2- Relação entre as tensões de cisalhamento e normal sob uma superfície de ruptura para cinco diferentes condições geológicas (Wyllie $\mathcal{E}$ Marh, 2004)

Na Figura 2 envoltória (1), se o preenchimento for de material fraco como argilas o ângulo de atrito será baixo, mas pode ter alguma coesão. Se o preenchimento for calcita, selando essas paredes a coesão será importante. Na envoltória (2) a coesão é anulada e o ângulo de atrito $(\varphi)$ é dependente do grão da rocha. Na envoltória (3) a coesão é anulada e o ângulo de atrito é composto pelo atrito da rocha e da irregularidade ou aspereza da superfície. Na envoltória (4) a ruptura pode ocorrer em parte, na rocha intacta e ao longo das superfícies de descontinuidades. Na envoltória (5) são maciços compostos de grão fino, com um ângulo de atrito baixo, mas sem fraturas resulta em alta coesão (Wyllie \& Marh, 2004).

\subsection{Coesão}

Em muitas aplicações práticas, o termo coesão é usado para referir-se a uma quantidade matemática relacionada com a rugosidade da superfície. A coesão é, conforme já descrito, a tensão de resistência ao cisalhamento na ausência de tensão normal. Fiori \& Carmignani (2009) dizem que a resistência ao cisalhamento é essencialmente composta por três partes: ângulo de atrito $(\varphi)$, coesão $(c)$ e tensão normal $(N)$, mas ao longo de uma fissura a coesão é anulada ou quase se anula conhecida por coesão básica. A atração química entre estas partículas proporcionada por carbonatação, sílica, óxidos de ferro, dentre outras substâncias, responde muitas vezes por altos valores de coesão e pode provocar uma resistência independente da tensão normal atuante no plano e constitui uma coesão real, como se uma cola tivesse sido aplicada entre os dois corpos.

\section{6 Ângulo de atrito}

Atrito é a nomenclatura dada à interação entre dois corpos em contato íntimo e em condições de movimento relativo. Quando dois corpos estão em contato e em equilíbrio relativo devido à ação de forças externas, as resultantes de tais sistemas de forças, em cada corpo, devem apresentar a mesma intensidade, mesma direção e sentidos opostos. Segundo Fiori \& Carmignani (2009), o ângulo de atrito pode ser entendido como sendo o ângulo máximo que a força transmitida pelo corpo à sua superfície pode fazer com a normal ao plano de contato sem que ocorra deslizamento. Para uma superfície lisa sem preenchimento, ou fraturada, a coesão é anulada e a resistência ao cisalhamento se torna apenas dependente do ângulo de atrito do material da rocha. Este ângulo é conhecido como ângulo de atrito básico e poderia ser determinado em ensaios diretos de cisalhamento em superfícies de rochas macias preparadas por meio de uma limpeza e corte com serra diamantada. É possível estimar o valor do ângulo de atrito através do diagrama de Mohr (Figura 2 envoltórias 2, 3 e 4) e desta forma assumir ângulos de atrito pequenos em rochas de grão fino ou ângulos de atrito maiores em rochas de grão grosso (Biblioteca digital,2014). 


\subsection{Volumetria dos blocos}

A volumetria dos blocos é um indicador extremamente importante do comportamento dos maciços rochosos. As dimensões dos blocos são determinadas pelo espaçamento das descontinuidades, pelo número de famílias e pela persistência das descontinuidades que delimitam os potenciais blocos. $\mathrm{O}$ número de famílias e a orientação determinam a forma dos blocos de rocha, que podem ter a aparência de cubos, paralelepípedos, romboedros, prismas, etc.. Contudo as formas geométricas regulares são mais a exceção do que a regra, uma vez que as descontinuidades de qualquer família são raramente paralelas de um modo consistente (Fiori \& Carmignani 2009).

\subsection{Contexto geológico}

Os terrenos que constituem a mina mangueirão encontram-se, na sua maior parte, inseridos no Complexo Metamórfico Vacacaí, unidade vulcano-sedimentar, com estrutura em forma de lente irregular, no sentido norte/ sul, com idade no proterozoíco inferior de 750 Milhões de anos, tem como base o gnáisse do Complexo metamórfico Cambaí, a área também abrange a Suíte Granítica Caçapava do Sul. A unidade metavulcanossedimentar é constituída por lentes de mármore e xistos provenientes de metapelito, grafita xisto, quartzitos, anfibolito e níveis de metavulcânicas intermediárias, todo o conjunto metamorfizado, observa-se também intrusões de diabásio (CPRM, 2000). O calcário é uma rocha sedimentar depositada em bacias por correntes marítimas e formada por micro-organismos ou por precipitação química do carbonato de cálcio. O calcário da área é originado por precipitação química, que por pressão e temperatura sofreu um processo de metamorfismo, formando rochas metamórficas de calcário, este material pode apresentar-se tanto de forma calcítica, com composição mineralógica $\mathrm{CaCO}_{3}$, ou dolomítica, de composição $\mathrm{CaMg}\left(\mathrm{CO}_{3}\right)$ (Bortolotto,1987).

\subsection{Análise cinemática de taludes rochosos}

A análise cinemática é representada graficamente através da projeção estereográfica que pode ser definida como uma rede circular utilizada para a representação dos planos das descontinuidades. Estes planos podem ser representados numa rede estereográfica como pólos ou vetores, desta forma é possível definir as famílias de descontinuidades que compartimentam o talude, a partir das orientações das diversas descontinuidades medidas. Uma família de descontinuidades particular é representada através de uma nuvem de pontos, cada um representando o pólo de uma descontinuidade (Fontinhas, 2012). A intersecção do plano com a superfície da esfera é um círculo maior, a reta perpendicular ao plano e passando pelo centro da esfera intersecta esta em dois pontos diametralmente opostos designados por polos do plano (Fiori \& Carmignani 2009).

Para realizar a representação manual de um plano pelo "círculo maior" e pelo pólo no plano equatorial de projeção, pode-se utilizar a rede de projeção como auxiliar. Começa por se assentar sobre a rede, uma folha de papel vegetal que pode girar em torno do centro da rede, recorrendo-se para tal a um alfinete que serve de eixo. Na folha de papel vegetal marca-se o ponto correspondente ao Norte da rede e em seguida, a partir deste, marca-se o strike a dip direction da descontinuidade medida sobre a periferia da rede no sentido dos ponteiros do relógio (Figura 3-a).
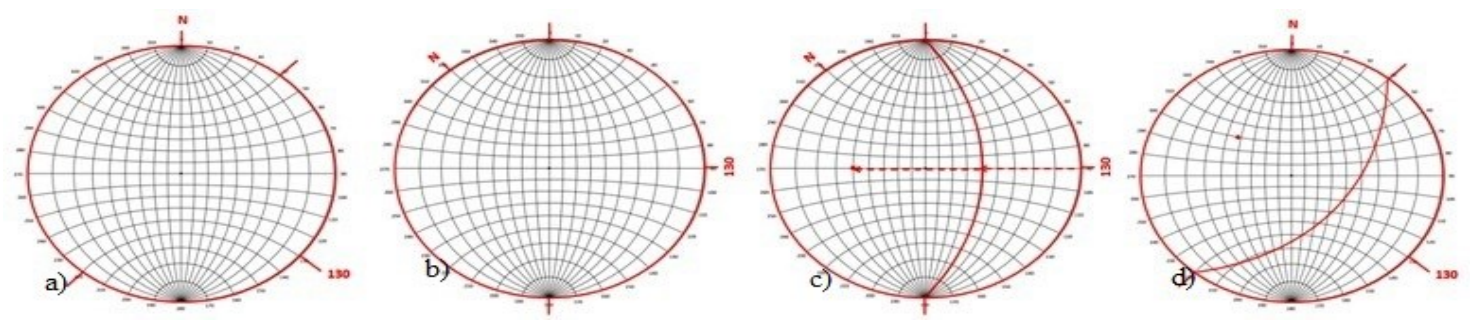

Figura 3 - Representação manual de cada etapa de um plano pelo "círculo maior" e pelo pólo - strike $40^{\circ}$, dip direction $130^{\circ}$ dip50 $0^{\circ}$ com base na rede de projeção estereográfica. 
Em seguida roda-se a folha de papel vegetal por forma que o dip direction coincida com o eixo E-W da rede (Figura 3-b). Sobre este eixo e a partir da periferia da rede mede-se o dip do plano, após o que se desenha no papel vegetal é o traço do plano sobreposto ao "círculo máximo" da rede de projeção. $\mathrm{O}$ pólo corresponderá ao ponto da rede, a marcar ainda com a folha de papel vegetal rodada, localizado sobre o eixo $E-W$ com um ângulo de $90^{\circ}$ do ponto de intersecção deste eixo com o traço do "círculo maior" (Figura 3-c). Depois destas operações, roda-se a folha de papel vegetal por forma ao Norte regressar à sua posição verdadeira. A Figura 3-d mostra a representação, obtida por esta via a partir das redes de projeção de um plano cuja reta de maior declive tem um strike de $40^{\circ}$ a dip direction de $130^{\circ}$ e um dip de $50^{\circ}$. O plano aparece representado pelo traço do "círculo maior" e pelo pólo.

A projeção estereográfica permite a representação de círculos maiores e pólos no plano horizontal que contém o equador (plano equatorial). Esta representação pode ser conseguida, tal como se mostra na Figura 4, ligando todos os pontos do circulo maior situados sobre a esfera de referência e pólo com o zénite (ponto de intersecção da reta vertical que passa pelo centro da esfera com a superfície do hemisfério superior). As projeções estereográficas do círculo maior e do pólo são dadas pelas intersecções das respectivas linhas de projeção com o plano equatorial. A projeção referida no parágrafo precedente é conhecida por projeção igual ângulo. Nesta projeção, qualquer círculo maior é representado por um arco de circunferência no plano equatorial de projeção. (Fiori \& Carmignani 2009).

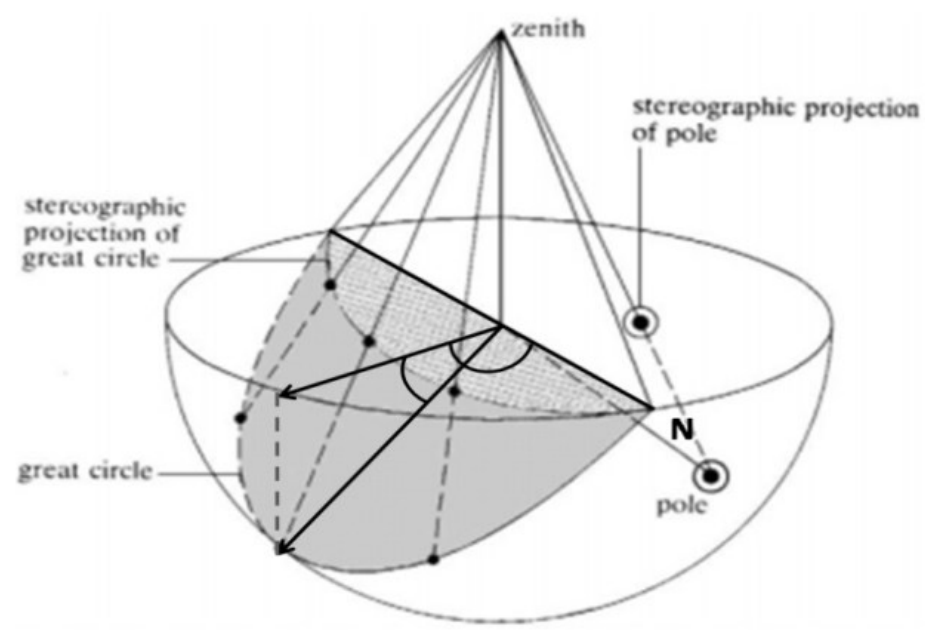

Figura 4 - Projeção igual ângulo de um círculo maior e do respectivo pólo. Fonte: Brady and Brown (1985).

Os tipos de rupturas são definidos de acordo com a geometria com que esta ruptura ocorre nos maciços rochosos, desta forma estão condicionadas ao grau das fraturas e suas atitudes e distribuição das descontinuidades em relação ao talude. Assim os parâmetros de resistência das descontinuidades influenciam na estabilidade do talude. A maneira mais simples de buscar essas informações é a medida da orientação através de uma bússola na face do talude. Fazendo essa análise de distribuição das descontinuidades num maciço rochoso, pode-se verificar se existem conjuntos com orientações distintas, se estas representarem certa regularidade, pode-se assim, recorrer ao auxílio de redes de projeção estereográfica e agrupar as descontinuidades em famílias (Fontinhas 2012 apud ISRM, 1978). Essa análise ajuda na identificação de diferentes tipos de rupturas: circular, planar, cunha e tombamento.

Ruptura circular - Figura 5: Pode ocorrer em maciços rochosos muito fraturados, mas é mais frequente em solos. Segundo (Fontinhas 2012 apud Hoek \& Bray 1981) uma fratura pouco espaçada, com pressões intersticiais suficientemente elevadas, assim como uma meteorização intensa no caso dos maciços rochosos, pode causar este tipo de movimento. Nas rupturas circulares as superfícies de deslizamento são muitas vezes visíveis ou podem ser inferidas pela prospecção in situ. As dimensões 
destas rupturas variam muito, podem movimentar desde poucos metros de material até vários hectares de terra.

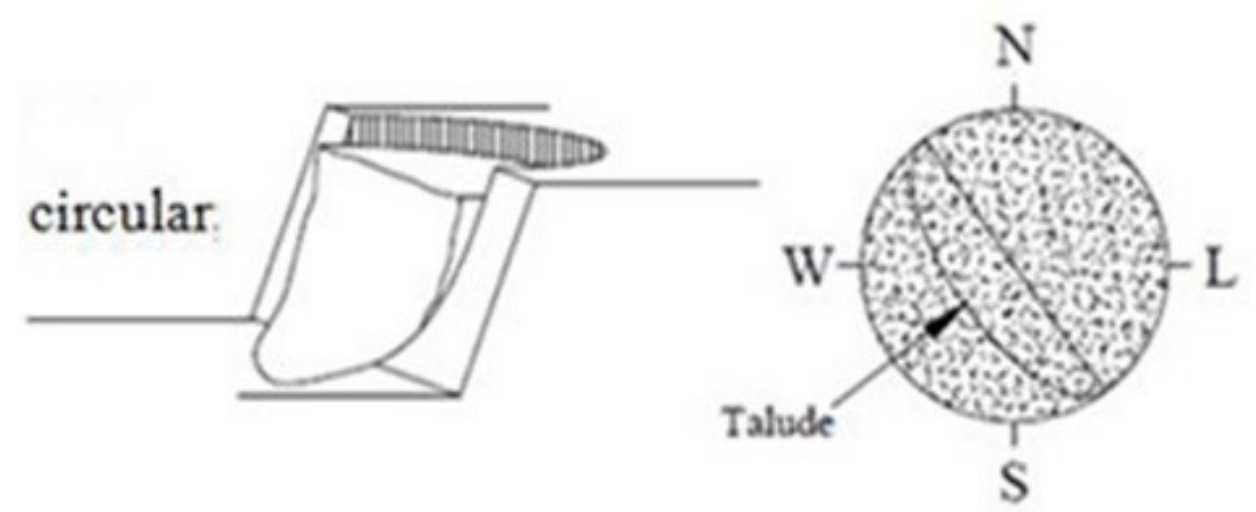

Figura 5 - Mecanismos de ruptura circular e a sua representação estereográfica (Hoek e Bray, 1981)

Ruptura planar - Figura 6: Este tipo de ruptura ocorre quando o strike do plano de deslizamento é aproximadamente paralelo à face do talude, tendo uma diferença inferior a $20^{\circ}$, e o ângulo de inclinação da descontinuidade ao longo do qual se dá a ruptura, deve ser menor que o ângulo da face do talude, permitindo que o material acima daquele deslize por gravidade. Este tipo de ruptura ocorre também por ação de forças como a pressão intersticial e acelerações sísmicas, sendo o volume de rocha deslocada ditado pela persistência das descontinuidades (Fontinhas, 2012). Este tipo de ruptura pode movimentar milhares de metros cúbicos de rocha numa só ruptura, mas para isto é necessário que esse bloco se destaque, tornando obrigatória a existência de descontinuidades laterais perpendiculares à face do talude para permitir assim a livre ruptura do bloco. Fiori \& Carmignani (2009) dizem que para ocorrer uma ruptura planar é necessário que essas estruturas sejam aflorantes e o ângulo de inclinação do plano de deslizamento tem que ser maior que o ângulo de atrito do mesmo plano.

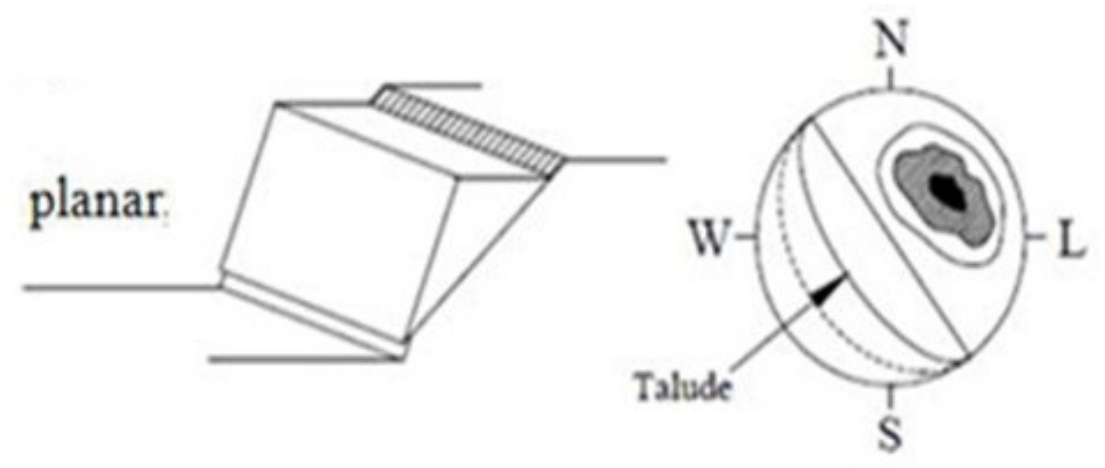

Figura 6- Mecanismos de ruptura planar e a sua representação estereográfica (Hoek e Bray, 1981)

Ruptura por cunha - Figura 7: A intersecção de dois planos de descontinuidades com direções divergentes formam um bloco em forma de cunha. Para que este tipo de ruptura ocorra, é necessário que a linha de intersecção dos dois planos aflore na superfície do talude com um ângulo de inclinação maior que o ângulo de atrito das descontinuidades (Fiori \& Carmignani 2009). É uma ocorrência de ruptura típica em maciços rochosos com várias famílias de descontinuidades, onde as atitudes, espaçamentos e persistências do maciço vão determinar a forma e volume da cunha. Uma característica deste tipo ruptura é a velocidade com que ocorrem, é extremamente rápida, e causam danos elevados, principalmente quando o bloco se desprende de alturas elevadas. 


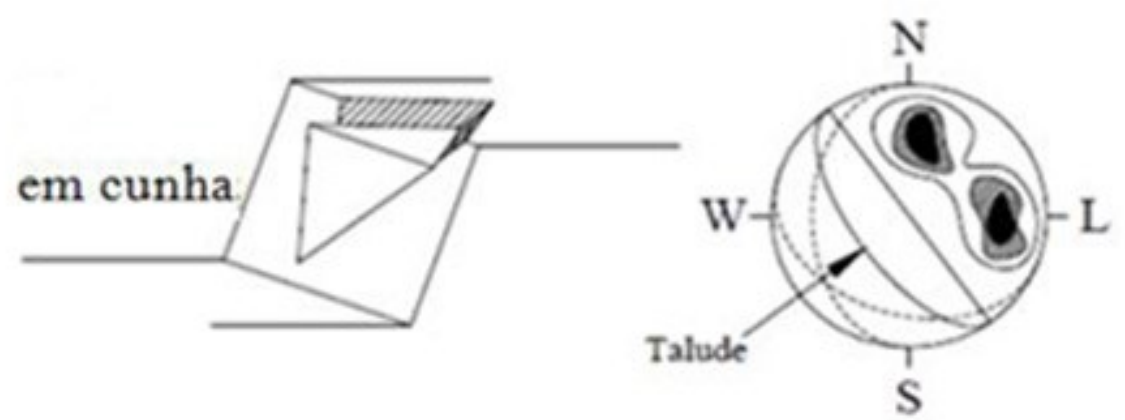

Figura 7- Mecanismos de ruptura em cunha e a sua representação estereográfica (Hoek e Bray, 1981)

Ruptura por tombamento - Figura 8: Segundo Fontinhas (2009) este tipo de ruptura é resultado da rotação de colunas ou blocos de rocha sobre uma base fixa. A família de descontinuidades deve estar paralela ou subparalela à face do talude com desvio máximo de $30^{\circ}$ entre ambos strikes. O tombamento de blocos depende da presença de planos estruturais bem definidos, como acamadamento, xistosidade, falhas, juntas e outros. Esta situação pode originar também deslizamentos, se existir uma inclinação progressiva do talude sem existir colapso, o bloco pode se desprender do talude e deslocase para frente, movimentando-se rapidamente pela face do talude, podendo fraturar-se, rolar ou deslizar. As condições mais favoráveis para ocorrer tombamento são quando uma família mergulha contra a vertente e é inclinada a ângulos superiores a $\left(90^{\circ}-\varphi\right)$ e quando mergulha a favor devera ser inferior ao ângulo de atrito (Fiori \& Carmignani 2009).

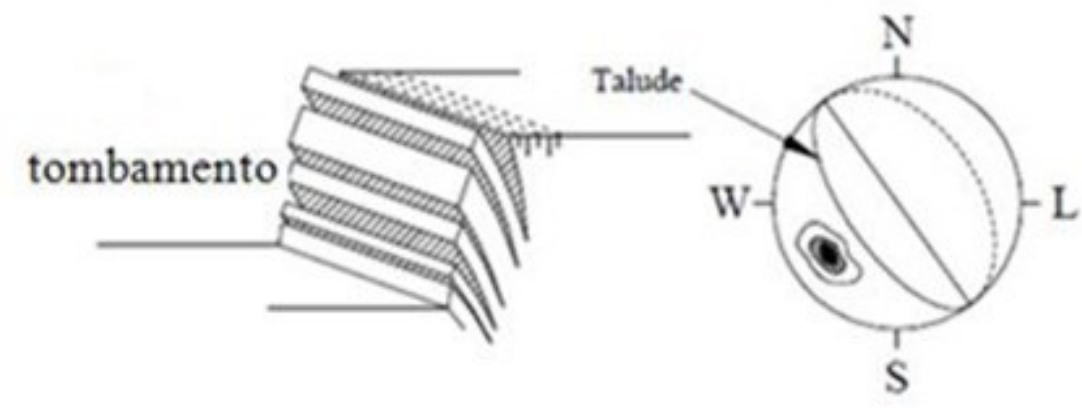

Figura 8 - Mecanismos de ruptura por tombamento e a sua representação estereográfica (Hoek e Bray, 1981)

\subsection{Estabilidades em relação ao deslizamento planar}

Serão abordados e explicados os cálculos de como se obtém o fator de segurança nos casos de ruptura planar e em cunha, por se tratar das condições de ruptura que mais se apresentam na atual situação da mina. O deslizamento planar trata-se do caso mais simples de análise de estabilidade (Figura 9). Este desenho ilustrativo de uma ruptura planar ajuda a entender melhor como as forças atuantes e as forças resultantes agem em uma situação de instabilidade no talude. Neste caso a altura do bloco $\mathrm{H}$ tem a mesma altura da bancada, o ângulo da descontinuidade está representado por $\alpha \mathrm{e}$ varia de acordo com cada família, o ângulo da face da bancada está representado pelo $\beta$, a largura do bloco por (b) e a lâmina de água pelo $\mathrm{Z}$. 


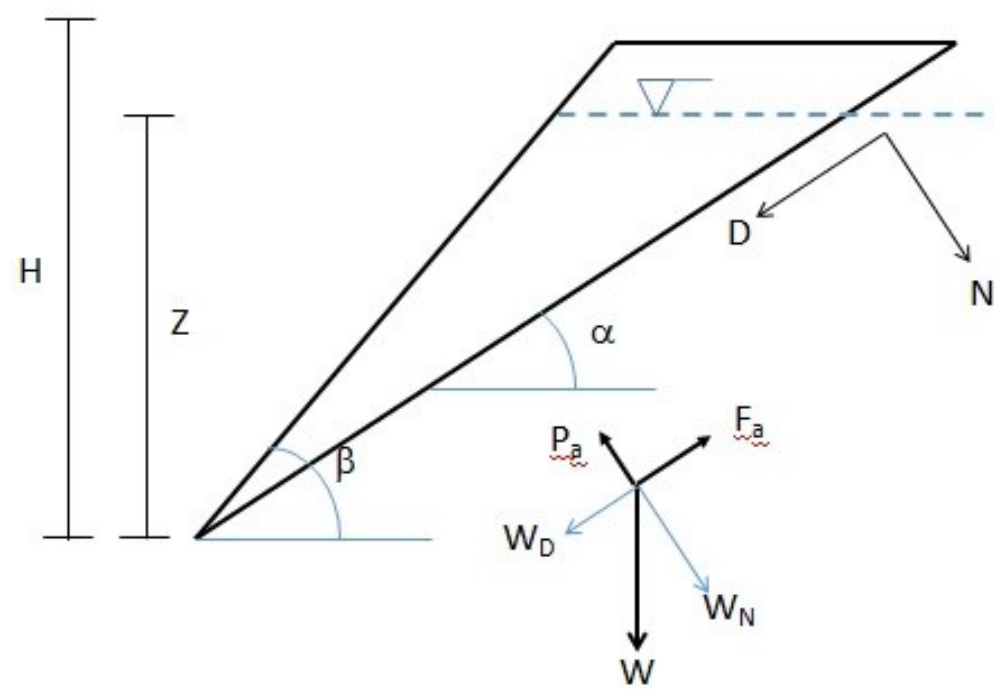

Figura 9 - Deslocamento planar - Forças atuantes e resultantes.

A partir das forças atuantes sobre a superfície de ruptura considerada, estabelece-se a equação do coeficiente de segurança. Nestas condições, a equação do coeficiente de segurança será dada por:

$\mathrm{S}=\frac{\mathrm{cA}+\mathrm{W} \cos \alpha \tan \phi}{\mathrm{W} \operatorname{sen} \alpha}$

Onde temos $c$ que representa a coesão do material, - A - é a área em contato do bloco, a massa deste bloco é representa por $\mathrm{W}$, o ângulo da descontinuidade por $\alpha$ e o ângulo de atrito é representado por $\varphi$.

O peso do bloco $\mathrm{W}$ é definido através da fórmula:

$W=\gamma_{b} V$

Onde $\gamma_{\mathrm{b}}$ é peso específico do bloco e o $\mathrm{V}$ o volume do bloco que é dado pela fórmula:

$\mathrm{V}=\frac{\mathrm{H}^{2} \mathrm{~b}}{2}(\cot \alpha-\cot \beta)$

Outros parâmetros a ser considerado são: A força de atrito $F_{a}$ que é representada pela fórmula:

$\mathrm{F}_{\mathrm{a}}=\mathrm{cA}+\mathrm{N} \tan \phi$

Direção paralela à descontinuidade $\mathrm{D}$, componente paralela ao deslizamento $\mathrm{W}_{\mathrm{D}}$ encontrado na equação:

$\mathrm{W}_{\mathrm{D}}=\mathrm{W} \operatorname{sen} \alpha$

A componente normal $N$ é igual a $W_{N}=W \cos \alpha$, que é o somatório das forças normais à descontinuidade.

Na ocorrência de água no local temos que levar em consideração a pressão de água que é dada pela fórmula: 
$\mathrm{P}_{\mathrm{a}}=\frac{\gamma_{\mathrm{a}} \mathrm{Z}^{2} \mathrm{~b}}{4 \operatorname{sen} \alpha} \mathrm{F}_{\mathrm{G}}$

Desta forma o fator de segurança é representado pela equação:

$\mathrm{s}=\frac{\mathrm{cA}+\left(\mathrm{W} \cos \alpha-\mathrm{P}_{\mathrm{a}}\right) \tan \phi}{\mathrm{W} \operatorname{sen} \alpha}$

Onde $P_{a}$ é a força resultante da pressão de água e o $F_{G}$ é o fator geométrico

$\mathrm{F}_{\mathrm{G}}=\frac{\tan \beta}{\tan \alpha}-1, \quad 0 \leq \mathrm{F}_{\mathrm{G}} \leq 1$

\subsection{Estabilidades de cunha}

O método de análise da estabilidade de blocos em forma de cunha (Figura 10) obedece aos mesmos princípios descritos para a análise da ruptura planar. A resolução é, contudo mais complexa uma vez que se torna necessário determinar as forças atuantes em cada um dos planos de deslizamento plano A e plano B. $N^{\prime}$ representa a força normal efetiva, ou seja, já descontada a pressão de água. O fator de segurança neste caso é encontrado através da equação:

$S=\frac{N_{a}^{\prime} \tan \left(\phi_{A}\right)+c_{A} A_{A}+N^{\prime}{ }_{b} \tan \left(\phi_{\bar{B}}\right)+c_{\bar{B}} A_{\bar{B}}}{W_{S}}$

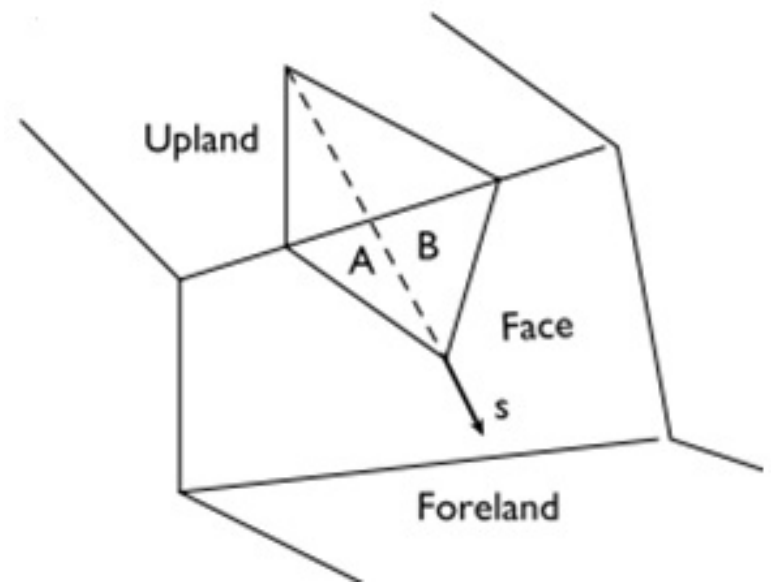

Figura 10 - Estabilidade de um bloco em forma de cunha - Vista isométrica do bloco. Fonte: Hoek e Bray, (1981).

O procedimento de análise passa por determinar o peso da cunha bloco e a área de cada face. O peso, bem como todas as forças externas, tais como pressões da água, cargas transmitidas por fundações e forças de ancoragem, é espacialmente decomposto em três direções, as duas normais aos planos de deslizamento e a da linha de intersecção destes.

\section{Materiais e metodologia}

Em cada talude selecionado foi realizado um conjunto de observações com vista à determinação dos parâmetros físicos e geométricos dos maciços rochosos aí ocorrentes. Assim, as orientações dos taludes bem como as das descontinuidades foram medidas recorrendo a uma bússola, sendo a altura 
aproximada dos taludes obtida através da relação geométrica entre a extensão medida sobre a face do talude e a sua inclinação. Todas as medições foram executadas com auxílio de fita métrica ou, quando necessário, recorrendo a uma régua graduada (abertura), para o caso da rugosidade e o estado de meteorização, assim como para enchimento, as informações foram obtidas através de observações em campo.

\subsection{Localizações dos taludes selecionados}

A área de estudo localiza-se na Mina do Mangueirão, com diversos taludes de escavação na extração de calcário dolomítico. Foram escolhidos sete taludes (Figura 11) para a realização das medidas, assim como coleta de amostras litológicas representativas.

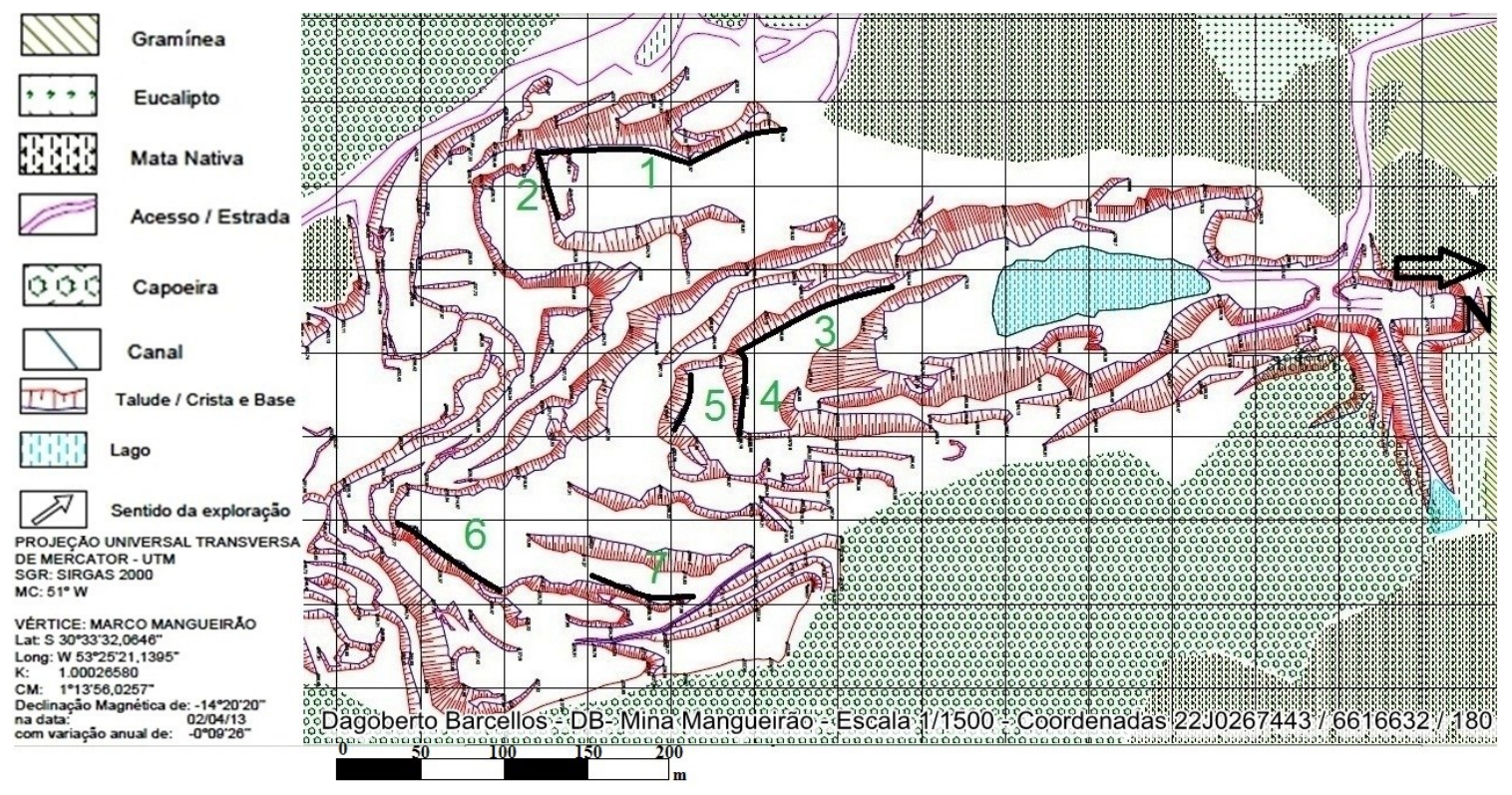

Figura 11 - Planta da mina mangueirão, localização da área de estudo talude de 1 ao7. Fonte Dagoberto Barcellos

\subsection{Levantamentos dos dados}

Para o levantamento estrutural através da linha de varredura - scanline - foram definidas frentes de análise considerando-se o tamanho da área de exposição e a viabilidade de medição no local escolhido, além de se optar por uma área representativa de todo o maciço deste depósito. Foram escolhidos taludes com direções perpendiculares, respectivamente visando gerar dados em duas direções distintas e ortogonais entre si para que a amostragem fosse representativa tridimensionalmente. Por questões de segurança e inacessibilidade, não foi possível efetuar um levantamento vertical de qualquer uma das frentes. Após seleção das áreas para levantamento foi esticada uma trena presa à frente de análise, procurando deixá-la na horizontal, essa trena serviu como a linha base das scanlines. A direção e inclinação da linha foram registradas e todas as descontinuidades que a intersectaram foram então amostradas e registradas em planilhas de amostragem, alem dos parâmetros de orientação, distância de intersecção, comprimento do traço, rugosidade do plano, preenchimento, abertura, além de qualquer observação julgada importante. Os dados referentes à orientação dos planos amostrados como, direção e mergulho foram medidos através de uma bússola, plotados e analisados estatisticamente. A distância de intersecção foi lida diretamente na trena de controle da scanline, os comprimentos foram medidos através de trena e quando inacessíveis, a distância foi estimada e os parâmetros rugosidade e persistência foram estimados, definidos e descritos. Em um primeiro momento os planos foram representados no estereograma com as orientações de todas as estruturas amostradas em cada scanline e os dados plotados na forma de pólos dos planos, além de terem sido confeccionados diagramas de densidade para definição das famílias de fraturas presentes. 
Foram calculados ainda os espaçamentos médios e frequência das descontinuidades para cada uma das famílias.

\section{Resultados e discussões}

Neste capítulo são apresentados e analisados os resultados obtidos no programa Steronet, das 307 orientações coletadas em campo nos sete taludes da mina mangueirão (Figura 12 - a). Após serem identificadas três principais famílias: A B e C que podem ser observadas na (Figura 12 - b), os trabalhos foram concentrados em duas famílias de maior expressão A e B. Por estar mais espalhada, a família B foi dividida em três grupos, para melhor representatividade: Família B1, Família B2 e Família B3 como mostram a (Figura 12 - c) e suas atitudes na Tabela 1. Pode-se dizer, que a Família A é a mais expressiva, pois ela representa as atitudes do depósito, ou seja, o ângulo em que o corpo esta mergulhando. Na família $C$ não foi identificada uma densidade significante que justificasse uma análise, pois levando em consideração as observações de campo, essas fraturas podem ser resultantes do desmonte, devido ao grau de verticalidade e pouca persistência.

\begin{tabular}{|l|c|c|c|}
\hline Familias & Traço & Strike & Dip \\
\hline Família A & & $176.5^{\circ}$ & $24.4^{\circ}$ \\
\hline Família B1 & & $13.2^{\circ}$ & $47.4^{\circ}$ \\
\hline Família B2 & & $36^{\circ}$ & $52^{\circ}$ \\
\hline Família B3 & & $342^{\circ}$ & $59^{\circ}$ \\
\hline
\end{tabular}
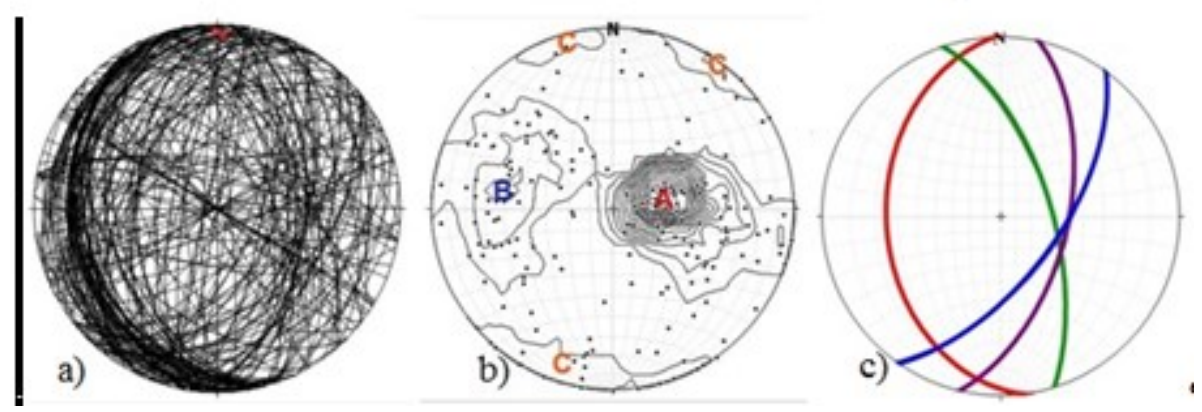

Figura 12-Projeção em rede estereográfica obtida programa estereonet9 - a) Projeção dos planos das 307 descontinuidades; b) Projeção dos respectivos pólos; c) Definição das famílias das descontinuidades.

\subsection{Frequências das descontinuidades}

A dimensão dos blocos em que o talude se encontra compartimentado são designadas por frequência, mecanismos de ruptura e deformação e podem variar em função da razão entre as dimensões do espaçamento das descontinuidades e as da escavação. Um espaçamento das descontinuidades demasiadamente pequeno traduz-se por uma perda de "coesão" do maciço rochoso, principalmente se for grande a área das descontinuidades. Nestas circunstâncias o modo de ruptura do maciço rochoso, normalmente é do tipo translacional, poderá ser predominantemente do tipo rotacional ou, ainda, de rolamento de pequenos blocos de rocha. 


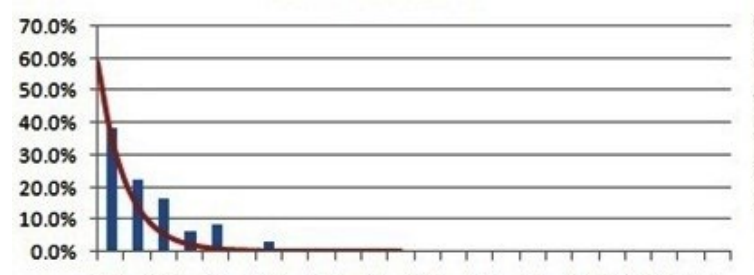

a)

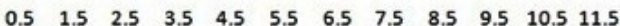

Espaçamento $(\mathrm{m})$

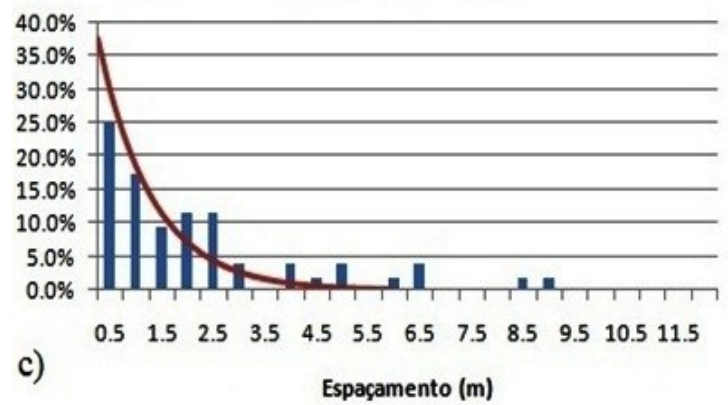

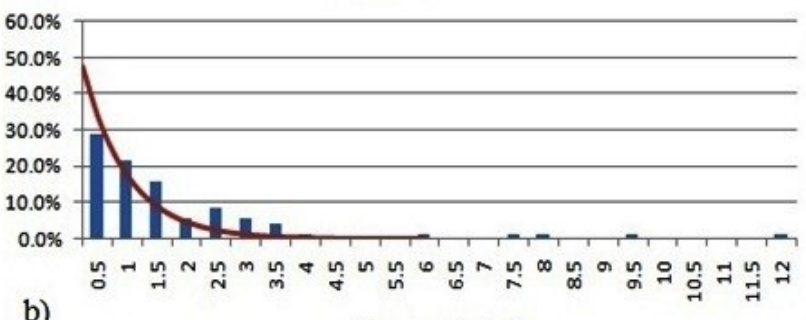

b)

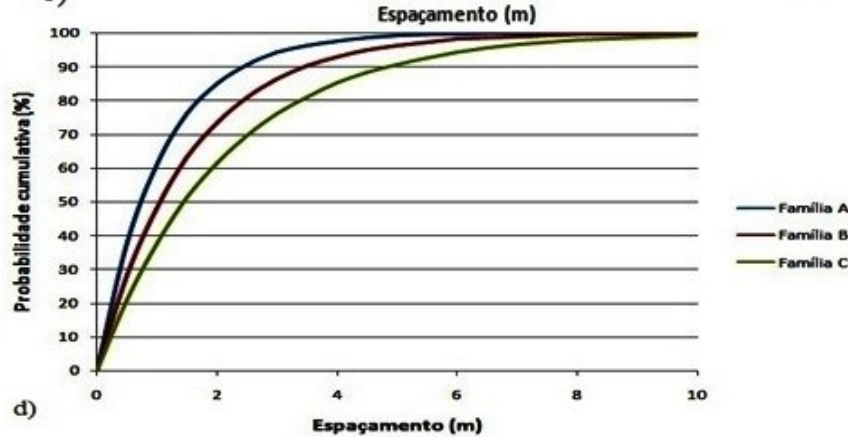

Figura - 13 - Histograma de frequência dos comprimentos das descontinuidades - Distribuição exponencial - a) Família A, b) Família B, c) Família $C$ e d) Frequência acumulada de todas as famílias.

A Figura 13 mostra os histogramas com a representação das 307 descontinuidades medidas nas setes bancadas distribuídas entre as três famílias A, B e C. Ao conjunto dos dados foram justapostas curvas representativas das funções exponenciais e acumuladas. A curva exponencial é mais representativa das descontinuidades de maior comprimento. Na Tabela 2 podem-se avaliar as frequências e espaçamento médio das descontinuidades referente a cada família.

Tabela - 1 Resultados de frequência e espaçamento médio das Famílias A, B, C.

\begin{tabular}{c|c|c} 
FAMÍLIA & FREQUÊNCIA $(\lambda)$ & $\begin{array}{c}\text { ESPAÇAMENTO } \\
\text { MÉDIO (x) }\end{array}$ \\
\hline A & 0,95 & $1,5 \mathrm{~m}$ \\
\hline B & 0,66 & $1,5 \mathrm{~m}$ \\
\hline C & 0,477 & $2,09 \mathrm{~m}$
\end{tabular}

\subsection{Análises de estabilidade}

Foram definidas oito simulações de frente de lavra e considerado um intervalo de $45^{\circ}$ para melhor cobrir várias situações de rupturas (Figura 14). Através da análise cinemática simples foi possível avaliar a influência das descontinuidades na estabilidade dos taludes escavados, e assim foi utilizado critérios para a formação das rupturas: plana, em cunha e por tombamento. Para avaliar o modo de ruptura e qual as suas repercussões no mundo real, deve ser tomado em consideração o ângulo de atrito dos planos das descontinuidades que cortam o talude, sendo aquele representado na rede estereográfica como um círculo de atrito ou zona crítica como mostra a Figura 14. Os pontos de interseção das descontinuidades ou do plano da família que podem formar uma ruptura estão indicados por setas e vão mostrar a possibilidade de identificar a zona onde existe potencial para a ruptura ocorrer e se a mesma esta dentro na zona critica. 


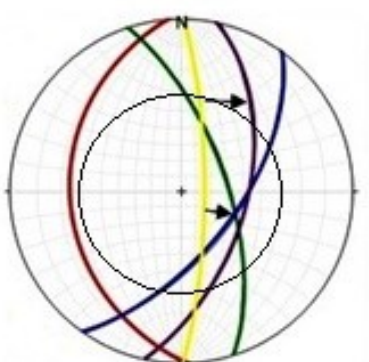

a)

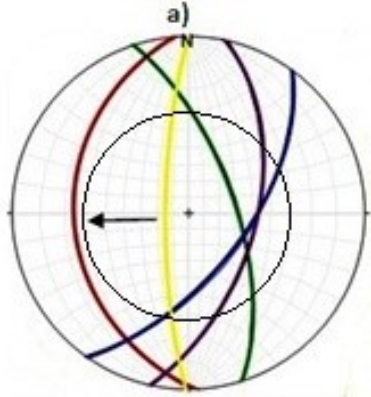

e)

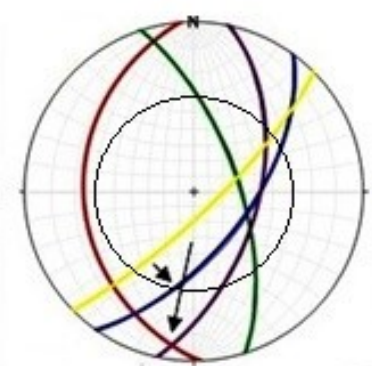

b)

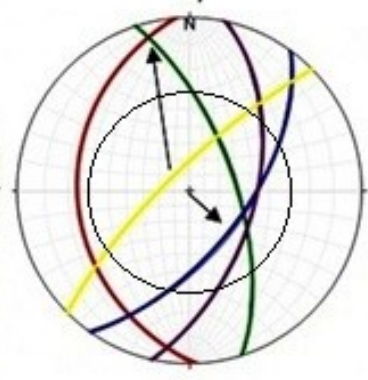

f)

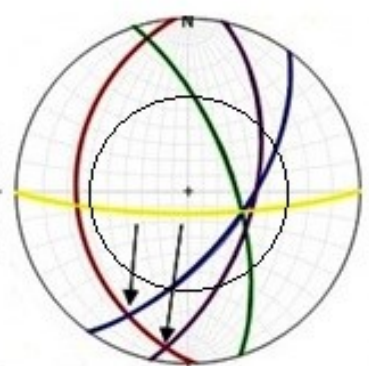

c)

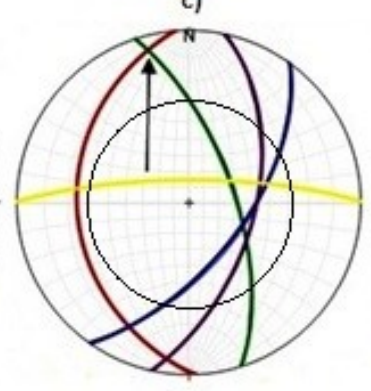

g)

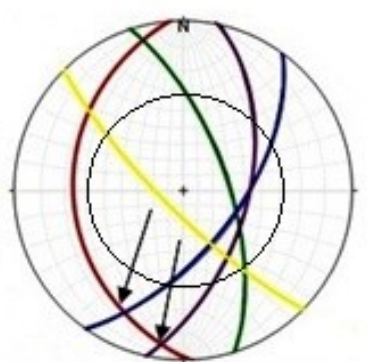

d)

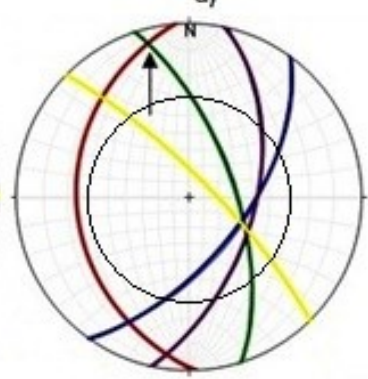

h)

Figura 14 - Projeção em rede estereográfica obtida programa estereonet9 das famílias de descontinuidades em oito diferentes situações de avanço de lavra. Em amarelo strike: a) $0^{\circ}$; b) 45 ; c) $90^{\circ}$; d) $135^{\circ}$; e) $180^{\circ}$; f) $225^{\circ}$; g) $270^{\circ}$ e h) $315^{\circ}$. Vermelho, família A; Roxo, família B1; Azul, família B2; Verde, família B3; Circulo de atrito $27^{\circ}$.

Na avaliação das rupturas, tanto planas quanto por tombamento, a avaliação do ângulo de inclinação de strike da descontinuidade com o talude foi necessária para identificar a família com provável influência na estabilidade, isto permitiu quantificar o risco de ruptura em cada caso. Entretanto, para as formações em cunha foi necessário identificar as linhas de interseção que têm mergulho menor do que a inclinação do talude. Neste caso pelo fato da rocha estar muito fraturada, foi assumido que a coesão seria anulada, devido a rocha não apresentar preenchimento nas fraturas representativo para se considerar uma coesão e ter uma abertura significativa entre as paredes, desta forma a coesão se limitou somente a rugosidade das paredes e o ângulo atrito básico referente às atitudes das descontinuidades. O calcário da mina mangueirão é considerado de grão médio, logo foi estimado um ângulo de atrito básico $(\varphi)$ de $27^{\circ}$, ou seja, um valor relativamente baixo a fim de se fazer uma analise conservadora. Através deste ângulo de atrito, foi criado o circulo de atrito, onde se trata de uma zona crítica de ruptura. Para estimar o fator de segurança, foi assumido que a altura do bloco $(H)$ teria a mesma altura da bancada, ou seja, que as descontinuidades destas famílias afloraram na superfície, desta forma assumindo uma situação de maior risco. $O$ ângulo da face da bancada $(\beta)$ utilizada pela empresa é de $75^{\circ}$ para todas as bancadas, assim foi utilizada a mesma inclinação para as simulações. Para os cálculos com a rocha saturada, foi assumido que a lâmina de água $(Z)$ teria também a mesma altura do bloco, devido o inverno da região é muito rigoroso com ocorrência de muitas chuvas, que deixa o solo encharcado, assim não considerando somente águas subterranes, mas também as superficiais.

\subsection{Análises dos resultados}

Começando com o primeiro talude estudado da Figura 14 (a), que esta sendo cortado por todas as famílias de descontinuidades. Analisando as condições cinemáticas, pode-se observar uma formação planar, com a Família B1, formação em cunha com Família B2 e B3 e por tombamento com a Família A. A direção do plano de deslizamento planar é aproximadamente paralela à face do talude, com diferença inferior a $20^{\circ}$ no strike, desta forma pode ocorrer ruptura planar. A formação em cunha, nos dois casos as famílias que estão com inclinações dentro da zona crítica, ou seja, dentro do circulo de atrito, os cálculos mostram um fator de alto risco (Tabela 2). Pode-se notar também formação por tombamento com a Família A, mas devido a seu mergulho de $24,4^{\circ}$ não ocorrerá a ruptura, mesmo 
com a descontinuidade sendo paralela à face do talude e tendo um desvio menor do que $30^{\circ}$ no strike, pois ela está fora da zona crítica.

A análise efetuada na Figura 14 (b), permite observar que a situação se repete, existe condições cinemáticas para ocorrer formação de ruptura planar, devido o ângulo de a descontinuidade agora com a Família B2 estar paralela a sua face. Nota- se na Tabela 2, que o os cálculos de fator de segurança para esse caso é muito baixo, não está atendendo o mínimo de segurança. Já a formação em cunha ganha maior fator de segurança devido à intersecção estar fora da zona crítica, mas com o calculo com a rocha saturada, a situação muda completamente.

No terceiro e no quarto caso da Figura 14 (c e d), o processo é semelhante, existem condições de formação de duas cunhas devido às intersecções entre as Famílias A e B1 e Família A e Família B2. Foi analisado o caso de maior risco, intersecção Família A e Família B, ou seja, a mais próxima da zona crítica, o fator de segurança na Tabela 2 mostra-se razoável a seco, mas muito baixo com a rocha saturada.

No quinto caso da Figura 14 (e) existe definição de formação de ruptura plana devido à orientação da Família A ser subparalela a face do talude, e ter uma diferença inferior a $20^{\circ}$ no strike, mergulhando na mesma direção. Pode-se dizer que o fator de segurança com a rocha seca está acima do mínimo de estabilidade, o ideal é acima de 1.5 (Tabela 2), mas já com a rocha saturada ao que tudo indica, ocorrerá ruptura planar, mesmo estando fora da zona crítica. Com a Família B1 existe formação de tombamento mais o mergulho da descontinuidade é favorável a estabilidade.

Através da análise cinemática efetuada no caso (f, g, h) da Figura 14, observa-se existir condições mecânicas para ocorrer formação de tombamento na Figura (f) com Família B2 devido às orientações da descontinuidade ser subparalelas a face do talude com uma inclinação contraria e com uma diferença inferior a $30^{\circ}$ no strike, mas mais uma vez o mergulho não é o suficiente para ocorrer à ruptura mesmo cortando a zona crítica.

As formações em cunhas devido às intersecções das Famílias A e B3, os cálculos asseguram um fator de segurança bem elevado, mesmo com a rocha saturada, logo se acredita que a ruptura não acontecerá, e com isto torna-se uma boa opção de avanço de lavra.

Tabela - 2 - Resultados de Fatores de segurança, taludes secos e saturados e percentagem de quanto diminui o FS

\begin{tabular}{c|c|c|c|c|c|c|c}
\multicolumn{2}{c|}{ Taludes } & \multicolumn{2}{c|}{ FS 1 seco } & \multicolumn{2}{c|}{ FS 2 água } & \multicolumn{2}{c}{ Diferença FS 1 e FS 2 (\%) } \\
\hline Strike & Dip & Planar & Cunha & Planar & Cunha & Planar & Cunha \\
\hline $0^{\circ}$ & $75^{\circ}$ & 0,469 & 0,431 & 0,201 & 0,205 & 57,14 & 52,44 \\
\hline $45^{\circ}$ & $75^{\circ}$ & 0,398 & 1,272 & 0,102 & 0,735 & 74,37 & 42,22 \\
\hline $90^{\circ}$ & $75^{\circ}$ & - & 1,272 & - & 0,506 & - & 60,22 \\
\hline $135^{\circ}$ & $75^{\circ}$ & - & 1,272 & - & - & - & 24,14 \\
\hline $180^{\circ}$ & $75^{\circ}$ & 1,123 & - & 0,838 & - & 25,38 & - \\
\hline $225^{\circ}$ & $75^{\circ}$ & - & 7,217 & - & 5,854 & - & 18,89 \\
\hline $270^{\circ}$ & $75^{\circ}$ & - & 7,217 & - & - & - & 19,29 \\
\hline $315^{\circ}$ & $75^{\circ}$ & - & 7,217 & - & - & - & 20,56
\end{tabular}

\section{Conclusão}

Foi possível verificar que em oito simulações de possibilidades de avanço de lavra para mina mangueirão, existem condições para ocorrer formação de ruptura por cunha, planar e tombamento. Grande parte destes mecanismos foi confirmada em observações realizada em campo. Com base nos resultados obtidos dos avanços propostos, foram classificadas como situação desfavorável as 
orientaç̃̃es $0^{\circ} ; 45^{\circ} ; 90^{\circ} ; 135^{\circ} ; 180^{\circ}$, pois pode ocorrer sim, ruptura planar e em cunha. Já as orientações de $225^{\circ} ; 270^{\circ}$ e $315^{\circ}$ mostraram um ótimo comportamento de estabilidade e os cálculos asseguram um fator de segurança elevado, podendo ser uma ótima opção de avanço de lavra, com segurança para equipamentos e principalmente para operários.

Para trabalhos futuros seria de interesse explorar outras ferramentas computacionais e laboratoriais para simulação de mecanismos de ruptura como: quedas de blocos e tombamentos, podendo este complementar e/ou confirmar resultados obtidos no âmbito do presente estudo.

Para trabalhos futuros, se sugere o estudo de outros cortes na mesma litologia, eventualmente de diferentes formações lito-estratigráficas do Complexo Metamórfico Vacacai, pois apesar de serem em traços gerais idênticos entre si, estas rochas ocupam uma vasta área da região, merecendo os numerosos taludes de lavra constituídos por essa rocha serem estudados em termos de estabilidade, de maneira a se obter maior representatividade em termos das técnicas de estabilização e proteção empregues.

\section{Agradecimentos}

Agradeço primeiramente a Deus por ter me dado a vida e o dom da sabedoria. Em memória a minha mãe Maria das Dores Madeira Paz e a demais familiares pelo apoio e o incentivo nestes três anos e meio de curso. A meu professor orientador Ítalo Gonçalves pela paciência e ajuda na construção deste trabalho. A minha esposa Taynara Oliveira da Rosa Paz pelo apoio desde o principio até agora para eu ter persistência e seguir adiante no que eu estava fazendo. E aos demais professores pela paciência de terem me ensinado muitas coisas que aprendi em sala de aula, que foram com certeza de muita valia na hora da realização deste artigo.

\section{Referências}

ALBERTO, PIO FIORI, LUIGI CARMIGNANI - Fundamentos de mecânica dos solos e das rochas; aplicações na estabilidade de taludes - 2 ed. rev. e ampl. : Ed. UFPR, 2009. 604 p.

BIBLIOTECA DIGITAL DE TESES E DISSERTAÇÕES teoria da resistência ao cisalhamento disponível em: http://bdtd.bce.unb.br/tedesimplificado/tde busca/arquivo.php?codArquivo=568. Acesso 01 agosto $2014.91 \mathrm{p}$.

BORTOlOTTO, O. J. Petrografia dos Mármores de Caçapava do Sul. Ciência e Natura: V. 9 - p. 37-65, (1987).

CPRM. Ministério de Minas e Energia. Companhia de Pesquisa de Recursos Minerais. Programa Levantamentos Geológicos Básicos do Brasil. Cachoeira do Sul, Folha SH.22-Y-A. In: PORCHER, C. A.; LOPES, R. C. (Org.). Estado do Rio de Grande do Sul. Brasília: CPRM, (2000).

FABIANA, SANTOS FERNANDES - Aplicação de fotogrametria terrestre digital na análise de descontinuidades em maciços rochosos - Universidade de são Paulo Instituto de Geociências dissertação de mestrado, geotectônica - São Paulo - 2010. 126 p.

B.H.G. BRADY AND E.T. BROWN - For underground mining - All Rights Reserved. First ed.- 1985 Second ed. -1993 Third ed -2004. 626 p.

ALEXANDRE, M. PEREIRA FONTINHAS - Avaliação da estabilidade de taludes de escavação grauvaques da Formação de Mértola - Aplicação do SMR - Dissertação para obtenção do Grau de Mestre em Engenharia Geológica - Geotecnia - Universidade Nova de Lisboa 2012. 97 p.

WIKIPEDIA.ORG - disponível em: http://en.wikipedia.org/wiki/Strike_and_dip. Acesso 25agosto 2014

WYLLIE, D e MAR, C. - Rock slope Engineering. Spon Press, London - 2004 New York, 431 p. 